\title{
THE REGIONAL IMPACT TRANSMISSION VIA INTERNATIONAL TRADE: AN ASIAN-IO APPROACH
}

\author{
Ibrahim \\ Tri Winarno \\ Melva Viva \\ Yanfitri $^{1}$
}

\begin{abstract}
Global financial crisis which began in the US in the latter part of 2008 hit a lot of countries in both trade and finance. In trade aspect, the crisis spread widely; in Indonesia, the total export value in 2009 dropped to 14.3\%. Therefore, the economy of China, tightly linked with Asian countries including Indonesia, which rapidly rose before the crisis but slowed after it should be monitored as this condition, could indirectly hold down Indonesia's GDP. Applying RAS method to update Asian IO data, this research has attempted to describe the trade structure of Asian countries in 2010. Also, it implemented a simulation of the impact of US and China's GDP decline and US exports on Indonesia's GDP, both at aggregate and sector levels. The result of the mapping shows that Indonesia is getting more dependent on China. Generally, the link between Indonesia's exported products and global production chain is weak. Indonesia's export commodities which are mostly of intermediate goods have low contribution towards value added. Moreover, the result of the simulation shows that 1\% decrease in China's GDP has greater impact on Indonesia's GDP (0.14\%) than that of the US (0.05\%) and EU (0.07\%) though with similar point.
\end{abstract}

Keyword: Trade Interactions, Input Output Model

JEL Classification: F16, R15

1 Researcher on Economiç Research Group, Department of Ecomomic Research and Monetary Policy, Bank Indonesia.The views on this paper is solely of the authors and not necessarily reflect the views of Bank Indonessia. E-mail: ibrahim@bi.go.id, t_winarno@ bi.go.id, melva_vg@bi.go.id, yanfitri@bi.go.id 


\section{INTRODUCTION}

The global economy tends to be closely linked with increasing transaction in goods and money market, which leads to higher dependency across countries. The economic cycle of one country with great affect to the world trade will also affect the other countries, particularly his major trading partners. The transmission mechanism of economic cycle from one country to another can be described through goods trade and financial channel. Economic turmoil in developed countries at the early stage is quickly transmitted through financial market, before being transmitted to the next stage via trade. The latter impact is stronger and more stable, and is expected to last longer. As it continues to the next stage, the crisis might be prolonged when the impact spread within the region, and the impact reverse back to the origin country on the second round.

The recent weakening of the global growth was triggered by developed countries. Financial crisis of 2008 in the United States which has not been fully recovered was followed by debt crisis in Europe and natural disaster in Japan2011. The growth of global economy improved in 2010. On the other side, the slowdown of developing countries economy was apparent even though the growth was still high. Developing countries in Asia with China as the driving force are still showing a relatively good performance compared to other regions in the world.

In line with the global economic slowdown, the volume of global trade and the price of commodities were also weakening in 2011. This development would directly affect the trade partner countries, which depends on external demands. On the other hand, beside indirect spilled over from other economic slowdown, the next stage impact may lead to the weakening of domestic demands on certain country.

With open economic system, Indonesia had also encountered direct and indirect impacts from the slowdown of other countries. For this reason, it is important to understand the relative position of Indonesia in the global economic linkages. This will be a strong basis in formulating a better and more comprehensive economic regulation. One powerful tool in analyzing the relationship across sectors and across countries through trade channel is the Asian Input Output (AIO) table. With Asian IO table, we can simulate both direct and indirect impact of the slowdown in certain countries, particularly where Indonesia has involved in trade agreement. This paper is expected to complement existing studies and this subject.

Explicitly, current paper aims to analyze the structure of Indonesia's production, to measure the direct impact of the downturn in US, EU, and China's economy on Indonesia's GDP, and to analyze the indirect impact of the decline on Indonesia's outputs. This paper sets some limitations. For instance, the Input Output table analysis used on this paper applies static-data which was in accordance with the characteristics of a country at certain period; thus, it cannot be used to project the future trends. Moreover, using RAS method to update the data assumes there are no changes on unobserved variables within observation period of 2000 to 2010. 
The next section will discuss the underlying theory of Input Output model. Section three provides the data and method we use on this paper, while section four presents the result and analysis. Section five outlines the conclusion and will close the presentation.

\section{THEORY}

Input-output analysis is essentially a theory of production, based on a particular type of production function. Its key relationships are technological, which involve some quantity of input and output during the process of production. The optimization from the supply side is neglected on this framework by assuming proportional input to output relationship. On the other side, the optimization from demand side is also excluded as for every man-hour of labor input, a fixed amount of each consumer good is required as input. This way, the consumers are treated as technologically determined production process, hence not as choice-making organism (Christ, 1955).

Internalizing spatial aspect leads to Inter Regional Input Output. On the global perspective, the model includes the trade across countries. The main advantage of the model is we can calculate the impact of certain shock originated from one country or group of countries to the rest ones, transmitted via global trade network.

This paper used Asian International Input-Output (AIO). AlO table was compiled and published by the Institute of Developing Economies Japan External Trade Organization (IDEJETRO) every five year. This table was used to analyze the structure of industry and trade linkages in Asia-Pacific economy.

AIO table provides detailed information on the structure of international input and output for intermediate and final goods and the relationship between production and trade within nine countries in Asia-Pacific. This includes Indonesia, Malaysia, Philippines, Singapore, South Korea, Taiwan, Thailand and Japan as well as the US. Furthermore, AIO table provides information on trade in Hong Kong S.A.R., EU, and Rest of the World (ROW) and some other data (see Appendix 1). Until now, AlO table is available for 1985, 1990, and 2000 edition. AIO table explains how the input used by certain country is related with the output of another country through coefficient function. The rows at AIO table represent production (output) of a country which becomes the input in other country.

A side from its strengths, AIO table also has weakness as it requires time and plenty resources to create the table. For this reason, the frequency of AIO publication has a wide interval. At present, the latest AIO table is year 2000 which was published in 2006. Meanwhile, the world economy keeps moving and changing. For example, at this time, trade in Asia-Pacific has entered a new phase following the role of China as the largest producing country. In line with it, the use of AIO table for year 2000 data is considered irrelevant in analyzing the economic 
trade correlation among countries in Asia-Pacific at present. Therefore, this paper will update the AIO table data at country and sector level, using data in 2010.

\subsection{Updating AIO table}

Updating AlO table take advantage from manual chart provided by Pula and Peltonen (2007) did similar research and updated 2006 AlO table. The chart comes with formula and eases the process of updating (Appendix 2). On current paper, we update for 2010 data on the basis of $2000 \mathrm{AlO}$ table. In general, the data for 2010 edition were taken by multiply data 2000 with its own growth rate within the period of 2000 to 2010. The steps and the updating procedures for 2010 are explained below.

\section{A. Intermediate Demand (A)}

- Value Added $\left(V_{t+1}^{j}\right)$. Growth rate of the value added from national account.

- Total Output $\left(\mathrm{X}_{t+1}^{j}\right)$. Total (gross) output was estimated by calculating the ratio of output over value added for manufacture sector. The data for value added manufacturing were derived from National Accounts while the data for output were gathered from industrial statistics.

- Imported Inputs $\left(A_{t+1}^{i j}\right)$. The calculation on growth rate of imported input was based on two sources. First, to maintain the consistency, we use data from National Accounts that involved trade data of goods and services. They do not provide information on trade direction; therefore we use the data from UNComtrade that has information on the types of imported goods, origin, and destination of the trade. We use the following formula to calculate the growth rate of imported input:

$\left(\right.$ int $M_{t+1}^{* i j}$ int $\left.M_{t}^{* i j}\right)=\left(M_{t+1}^{N A} M_{t+1}^{N A}\right) \star \frac{\left(\text { int } M_{t+1}^{C O M i j} / \text { int } M_{t}^{C O M i j}\right)}{\left(M_{t+1}^{C O M} / M_{t+1}^{C O M}\right)}$

Int $\mathrm{M}$ stands for import of intermediate goods; $\mathrm{M}$ stands for total import; NA is the abbreviation from National Accounts and COM is the abbreviation from UNCOMTRADE

- Freight and insurance and import duties $\left(B A_{t+1}^{j}, B A_{t+1}^{j}\right)$. Growth rate from freights and insurance and import duties is considered to be equal to the growth rate of import from National Accounts

\section{B. Final Demand (F)}

- Total consumption and investment $\left(C_{t+1}^{j}, l_{t+1}^{j}\right)$. The data on growth rate of consumption and investment were taken from National Accounts. Consumption is the sum of 
government and household consumption, while the investment is equal to the gross capital formation (gross fixed capital formation plus inventories)

- Imported Final Goods ( $\left.c F_{t+1}^{i j}\right)$ and Imported Capital Goods $\left(i F_{t+1}^{i j}\right)$

Growth rate is calculated based on the following formula:

$$
\begin{aligned}
& \left(c M_{t+1}^{* i j} / c M_{t}^{* i j}\right)=\left(M_{t+1}^{N A} / M_{t+1}^{N A}\right) * \frac{\left(c M_{t+1}^{C O M i j} / c M_{t}^{C O M i j}\right)}{\left(M_{t+1}^{C O M} / M_{t+1}^{C O M}\right)} \\
& \left(\operatorname{cap}_{t+1}^{* i j} / \mathrm{cap}_{t}^{* i j}\right)=\left(M_{t+1}^{N A} M_{t+1}^{N A}\right) * \frac{\left(\operatorname{capM}_{t+1}^{C O M i j} / \mathrm{capM}_{t}^{C O M i j}\right)}{\left(M_{t+1}^{C O M} / M_{t+1}^{C O M}\right)}
\end{aligned}
$$

NA is the abbreviation of National Accounts, and COM is the abbreviation of UNComtrade; cM and capM refer to the import from consumption and capital goods.

\section{Export (L)}

- Export to Hong Kong, EU15 and RoW $\left(\mathrm{L}_{t+1}^{\mathrm{iH}}, \mathrm{L}_{\downarrow}(\mathrm{t}+1)^{\uparrow} i \mathrm{O}, \mathrm{L}_{\downarrow}(\mathrm{t}+1)^{\uparrow} \mathrm{iW}\right)$. Growth rate was measured based on growth rate of export-based UNCOMTRADE trade and National Accounts

$$
\left(E X_{t+1}^{* i j} / E X_{t}^{* i j}\right)=\left(E X_{t+1}^{N A} / E X_{t+1}^{N A}\right) * \frac{\left(E X_{t+1}^{C O M i j} / E X_{t}^{C O M i j}\right)}{\left(E X_{t+1}^{C O M} / E X_{t+1}^{C O M}\right)}
$$

- Statistical Discrepancy $\left(\mathrm{Q}_{\downarrow}(\mathrm{t}+1)^{\uparrow} \mathrm{i}\right)$. The data were taken from National Accounts

\section{Total Intermediate Input/ Output}

Total intermediate input is the difference between the total input and the row sum from Freight Insurance up to Value Added. Meanwhile, total intermediate output is the difference between the total output and column sum from Statistical Discrepancy up to Final Demand. Should discrepancy between total sum of intermediate input and total output exist, we use the total intermediate input as valid one. This way, the difference between total intermediate input and output is put into statistical discrepancy; hence the total rate of intermediate input will be equal to the total intermediate output.

\section{E. Intermediate Demand}

Intermediate demand in each country was estimated using RAS method. 


\subsection{RAS method}

RAS method is a commonly used method to renew coefficient matrix in $\mathrm{t}+1$ in order to analyze input output ${ }^{2}$. Basically, this method is intended to find the suitable Leontief matrix so that the set of intermediate input/output has a consistent sum in the period of $t+1$. Updated coefficient matrix using this method has accommodated the change in technology, the relative price, and the incompleteness of data.

The underlying assumptions in RAS method are:

- The availability of IO matrix estimated from the previous year $\left(\mathrm{t}_{0}\right)$

- The availability of data in both rows and columns for the target year (year to estimate).

- The inquiry for multiplier to adjust the data in the rows and columns so that they fit the total target of intermediate input/output of the target year.

RAS method can simply be broken down as follows:

$$
\begin{aligned}
A_{1} & =\hat{r} A_{0} \hat{s} \\
& =\left[\begin{array}{ll}
r_{1} & 0 \\
0 & r_{2}
\end{array}\right] \times\left[\begin{array}{ll}
a_{11} & a_{12} \\
a_{21} & a_{22}
\end{array}\right] \times\left[\begin{array}{cc}
s_{1} & 0 \\
0 & s_{2}
\end{array}\right]=\left[\begin{array}{ll}
r_{1} a_{11} s_{1} & r_{1} a_{12} s_{2} \\
r_{2} a_{12} s_{1} & r_{2} a_{22} s_{2}
\end{array}\right] \\
F_{1} & =A_{1} \widehat{X_{1}}=\left(\hat{r} A_{0} \hat{s}\right) \widehat{X_{1}} \\
u^{*} & =F_{1} i \\
& =\left(\hat{r} A_{0} \hat{s}\right) \widehat{X_{1}} i \\
& =\left(\hat{r} A_{0} \widehat{X_{1}}\right) \hat{s} i \\
& =\widehat{r}\left(A_{0} \widehat{X_{1}}\right) s \\
v^{*} & =F_{1} i \\
v^{*} & =i^{\prime} F_{1} \\
v^{*} & =r^{\prime}\left(A_{0} \widehat{X_{1}}\right) \hat{s}
\end{aligned}
$$

2 Buetre and Esfahani (2000). Updating an Input Output Table for Use in Policy Analysis. The Australian Journal of Agricultural and Resource Economics 
The notation from the formula of RAS method above is as follows: $F_{0}=10$ matrix which serve as the benchmark; of $F_{1}=10$ updated matrix; $A_{0}=$ coefficient of the benchmark 10 matrix; $A_{1}=$ updated coefficient 10 matrix; $r$ and $s=$ rows and columns multiplier; $X_{1}=$ output vector from the most recent year; $u^{*} \& v^{*}=$ the rows and the columns of total intermediate input and outputfor the most recent year matrix; $i$ is the column vector of one.

The next discussion includes the steps from RAS method which are explained simply as follow?

1. The availability of 10 table in Year 0

\begin{tabular}{|c|c|c|c|c|c|c|}
\hline \multicolumn{7}{|c|}{$\begin{array}{c}\text { Table } 1 \\
\text { Table IO in } 0\left(F_{0}\right)\end{array}$} \\
\hline \multirow[b]{2}{*}{ Negara } & \multicolumn{3}{|c|}{ Intermediate Demand } & \multirow{2}{*}{$\begin{array}{c}\text { Total } \\
\text { Int.Output }\end{array}$} & \multirow{2}{*}{$\begin{array}{c}\text { Final } \\
\text { Demand }\end{array}$} & \multirow{2}{*}{$\begin{array}{c}\text { Total } \\
\text { Outpu }\end{array}$} \\
\hline & A & B & C & & & \\
\hline A & 50 & 100 & 0 & 150 & 50 & 200 \\
\hline B & 30 & 50 & 20 & 100 & 200 & 300 \\
\hline C & 20 & 50 & 30 & 100 & 100 & 200 \\
\hline $\begin{array}{c}\text { Total } \\
\text { Int.Input }\end{array}$ & 100 & 200 & 50 & 350 & 350 & 700 \\
\hline $\begin{array}{l}\text { Value } \\
\text { Added }\end{array}$ & 100 & 100 & 150 & 350 & & \\
\hline Total Input & 200 & 300 & 200 & 700 & & \\
\hline
\end{tabular}

3 The steps in RAS method were taken from Capilit. E presentation (Asian Development Bank) on 2 ${ }^{\text {nd }}$ Data Review Workshop, 7-12 December 2009 
2. Updating data for 10 table in Year 1

\begin{tabular}{|c|c|c|c|c|c|c|}
\hline \multicolumn{7}{|c|}{$\begin{array}{c}\text { Table } 2 \\
\text { Table IO in1 }\left(F_{1}\right)\end{array}$} \\
\hline \multirow[b]{2}{*}{ Negara } & \multicolumn{3}{|c|}{ Intermediate Demand } & \multirow{2}{*}{$\begin{array}{c}\text { Total } \\
\text { Int.Output }\end{array}$} & \multirow{2}{*}{$\begin{array}{l}\text { Final } \\
\text { Demand }\end{array}$} & \multirow{2}{*}{$\begin{array}{l}\text { Total } \\
\text { Output }\end{array}$} \\
\hline & A & B & C & & & \\
\hline A & & & & 160 & 40 & 200 \\
\hline B & & & & 150 & 250 & 400 \\
\hline C & & & & 120 & 180 & 300 \\
\hline $\begin{array}{c}\text { Total } \\
\text { Int.Input }\end{array}$ & 100 & 250 & 80 & 430 & 470 & 900 \\
\hline $\begin{array}{l}\text { Value } \\
\text { Added }\end{array}$ & 100 & 150 & 220 & 470 & & \\
\hline Total Input & 200 & 400 & 300 & 900 & & \\
\hline
\end{tabular}

3. Calculating coefficient matrix in year 0

\begin{tabular}{c|c|c|c}
\multicolumn{4}{c}{ Table 3 } \\
Coefficient Matrix in Year 0 \\
& \multicolumn{2}{|c}{ Intermediate Demand } \\
\hline Negara & A & B & C \\
\hline A & 0.250 & 0.333 & 0.000 \\
\hline B & 0.150 & 0.167 & 0.100 \\
\hline C & 0.100 & 0.167 & 0.150 \\
\hline
\end{tabular}

4. Coefficient matrix in Year 0 was multiplied with the Total Input at IO table in Year1 to fill intermediate demand in Year 1. Get the column sum for each row, then divide with the target for total intermediate output to obtain ratio $r_{1}$

Coefficient Matrix in Year O Multiplied with Total Output
\begin{tabular}{c|c|c|c|c|c|c} 
Table \\
Negara & A & B & C & $\mathbf{u}_{1}$ & \multirow{2}{*}{$\mathbf{u}^{*}$} & $\mathbf{r}_{\mathbf{1}}=\mathbf{u}^{*} / \mathbf{u}_{\mathbf{1}}$ \\
A & 50.0 & 133.3 & 0.0 & 183.33 & 160 & 0.873 \\
B & 30.0 & 66.7 & 30.0 & 126.67 & 150 & 1.184 \\
C C & 20.0 & 66.7 & 45.0 & 131.67 & 120 & 0.911
\end{tabular}


5. Ratio $r$ which had been obtained was multiplied with every digit in the rows so that addition from the rows equaled to the total target of intermediate output

\begin{tabular}{|c|c|c|c|c|}
\hline \multicolumn{5}{|c|}{$\begin{array}{c}\text { Table } 5 \\
\text { Adjustment of Values in Rows to Fit Ratio } r_{1}\end{array}$} \\
\hline \multirow[b]{2}{*}{ Negara } & \multicolumn{3}{|c|}{ Intermediate Demand } & \multirow[b]{2}{*}{$\mathrm{u}_{1}=\mathrm{u}$} \\
\hline & A & B & C & \\
\hline A & 43.6 & 116.4 & 0.0 & 160 \\
\hline B & 35.5 & 78.9 & 35.5 & 150 \\
\hline C & 18.2 & 60.8 & 41.0 & 120 \\
\hline
\end{tabular}

6. Get row sum, then compare to the total target of intermediate input in order to obtain ratio $s_{1}$

\begin{tabular}{|c|c|c|c|}
\hline \multicolumn{4}{|c|}{$\begin{array}{c}\text { Table } 6 \text { Addition of Values in Columns } \\
\text { and the Obtained Ratio } s_{1}\end{array}$} \\
\hline & \multicolumn{3}{|c|}{ Intermediate Demand } \\
\hline Negara & A & B & C \\
\hline A & 43.6 & 116.4 & 0.0 \\
\hline B & 35.5 & 78.9 & 35.5 \\
\hline C & 18.2 & 60.8 & 41.0 \\
\hline v1 & 97.4 & 256.1 & 76.5 \\
\hline $\mathbf{v}^{*}$ & 100 & 250 & 80 \\
\hline$s_{1}=v^{*} / v_{1}$ & 1.027 & 0.976 & 1.045 \\
\hline
\end{tabular}

7. Multiply the ratio $s_{1}$ with certain value of each column, by keeping their column sum equals to the total target of intermediate input.

\begin{tabular}{|c|c|c|c|}
\hline \multicolumn{4}{|c|}{$\begin{array}{l}\text { Table } 7 \text { Adjustment of Values in } \\
\text { Column to Fit Ratio } s_{1}\end{array}$} \\
\hline & \multicolumn{3}{|c|}{ Intermediate Demand } \\
\hline Negara & A & B & C \\
\hline A & 44.8 & 113.6 & 0.0 \\
\hline B & 36.5 & 77.1 & 37.1 \\
\hline C & 18.7 & 59.3 & 42.9 \\
\hline $\mathbf{v}^{*}=\mathbf{v}_{1}$ & 100 & 250 & 80 \\
\hline
\end{tabular}


8. Do iteration for steps 5 up to 7 in order to obtain ratio as close as possible to 1 .

\begin{tabular}{|c|c|c|c|c|c|}
\hline \multirow[b]{2}{*}{ Negara } & \multicolumn{3}{|c|}{ Intermediate Demand } & \multirow[b]{2}{*}{$u_{1}=u$} & \multirow[b]{2}{*}{$r_{1}=u^{*} / u_{1}$} \\
\hline & A & B & C & & \\
\hline A & 45.3 & 114.7 & 0.0 & 160 & 0.884 \\
\hline B & 36.2 & 76.6 & 37.2 & 150 & 1.177 \\
\hline C & 18.5 & 58.7 & 42.8 & 120 & 0.902 \\
\hline$v^{*}=v_{1}$ & 100 & 250 & 80 & & \\
\hline$s_{1}=v^{*} / v_{1}$ & 1.025 & 0.974 & 1.054 & & \\
\hline
\end{tabular}

\subsection{Backward and Forward Linkages}

Backward and forward linkages in a production were measured by using Leontief coefficient. Leontief coefficient at AIO table can be calculated as follows:

$$
a_{i j}=\frac{A_{i j}}{X_{j}}
$$

where $i$ = origin country; $j$ = destination country; $A_{i j}$ is the input from the origin country which is used by destination country $j$; and $X_{j}$ is the total production from economy $j$. Thus, AIO table can be figured as follows:

$$
\left[\begin{array}{cccc}
\alpha^{I I} & \alpha^{I M} & \cdot & \alpha^{I U} \\
\alpha^{M I} & \alpha^{M I} & \cdot & \alpha^{M U} \\
\cdot & \cdot & \cdot & \cdot \\
\alpha^{U I} & \alpha^{U M} & \cdot & \alpha^{U U}
\end{array}\right] \times\left[\begin{array}{c}
X^{I} \\
X^{M} \\
\cdot \\
X^{U}
\end{array}\right]+\left[\begin{array}{c}
F^{I I} \\
F^{M I} \\
\cdot \\
F^{U I}
\end{array}\right]+\left[\begin{array}{c}
F^{I M} \\
F^{M M} \\
\cdot \\
F^{U M}
\end{array}\right]+\ldots+\left[\begin{array}{c}
Q^{I} \\
Q^{M} \\
\cdot \\
Q^{U}
\end{array}\right]=\left[\begin{array}{c}
X^{I} \\
X^{M} \\
\cdot \\
X^{U}
\end{array}\right]
$$

For $\mathrm{F}^{\mathrm{ij}}$ = final demand vector (total sum of consumption and investment); and $\mathrm{Q}_{\mathrm{s}}^{\mathrm{s}}=$ export vector to Hong Kong, to EU, and to the Rest of the world. We can rewrite the equation above using matrix notation as follows:

$$
\mathrm{AX}+\mathrm{Y}=\mathrm{X}
$$

The formula to see the amount of input required to produce output is:

$X=(1-A)^{-1} Y=B Y$; for $B$ is the Leontief coefficient matrix 
$\mathrm{B}^{\mathrm{ij}}$ is part of the matrix that reflects the amount of production which is required by country i (origin country) to produce a unit of value added in country j (destination country). Leontief coefficient matrix can help to analyze the correlation of production across countries through their trade on intermediate goods.

\section{METHODOLOGY}

As explained before, this paper uses Inter Regional Input Output to analyze the impact of certain countries on Indonesia. The data used in this research were taken from Asian International Input Output (AIO) table which was compiled with that of Institute of Developing Economies Japan External Trade Organization (IDE-JETRO). AIO provided trade data of intermediate and final demand of 10 countries: Indonesia, Malaysia, Philippines, Thailand, Singapore, China, Taiwan, Japan, South Korea, and the US. The table is constructed with 5 years interval, and currently available for 1985, 1990, 1995, and 2000.

To update previous AIO table to AIO 2010, we use export-import data of 9 countries ${ }^{4}$ and Hong Kong, EU and Rest of the World. The export and import data are classified based on type of goods, country of origin, and destination country, based upon UNComtrade data from 2000 to 2010. Data on manufacturing output, GDP, and several other supporting data were taken from CEIC.

We made some adjustment on Hong Kong trade data. Based on Hong Kong trade statistics, re-export component in 2010 reached $97.7 \%$ from their total export. Re-export comprised of products that passed through Hong Kong without manufacturing process, hence no changes on product shape, size, or the function of the products. Re-export in Hong Kong was closely linked to the trade between China and its business partners. Thus, leaving it un-corrected will by far over estimate the actual ones.

Hong Kong trade data provide information including re-export based on countries which act as the origin country and destination country, as well as re-export across product type. Using these information, we adjust import of intermediate, consumer and capital goods in Hong Kong with the following formula:

$$
\begin{aligned}
& A_{H K}^{i j}=A^{i j}+\eta_{\text {int }}^{j} \star \gamma^{i j} \star L H^{i} \\
& C F_{H K}^{i j}=C F^{i j}+\eta_{\text {cons }}^{j} \star \gamma^{i j} \star L H^{i} \\
& i F_{H K}^{i j}=i F^{i j}+\eta_{c a p}^{j} \star \gamma^{i j} \star L H^{i}
\end{aligned}
$$

4 Taiwan's trade data is not available in UNCOMTRADE 


$$
\begin{gathered}
\gamma^{i j}=\frac{R X^{* i j}}{M^{* i}} \\
\eta_{g}^{j}=\frac{R X_{g}^{* j}}{R X^{* j}}
\end{gathered}
$$

Where $\mathrm{LH}^{\mathrm{i}}$ is the exporting country $i$ to Hongkong; $\gamma^{\mathrm{ij}}$ is the shared of re-export from country $i$ (source) to country $j$ (destination) towards total import from corresponding country $i$ to Hong Kong; and $\eta_{\mathrm{g}}^{j}$ is the shared of product type $g$ (intermediate, consumption and capital goods) towards total re-export to country $j$.

\section{RESULT AND ANALYSIS}

Referring to updated 2010 AlO table and the RAS method, this section outlines the analysis in two sections; first, the analysis of backward and forward linkages coefficients; and second, the analysis of value added dependency of certain countries towards domestic demand, intraregional trade, and trade with developed countries. In addition, this section provides analysis on 24 sectors in each country, including the simulation of GDP slowdown of or export reduction to developed countries US, EU, and China. Last part of this section will provide robustness check to see the consistency of 2010 AlO table.

\subsection{Aggregate Asian IO: Backward and Forward Linkages}

Backward linkages $(\mathrm{BL})$ coefficient show the amount of input obtained from other countries to produce domestic output, or often referred as the amount of import content of a country. Table 9 provide calculated BL coefficient using IO in 2000 and 2010.

Indonesia's BL in 2010 is higher than that in 2000 (1.72 to 1.87). High dependency on the output from other countries was experienced by China. In 2000, BL in China was as much as 2.57, almost equal to Japan and US, but now China's BL coefficient is as high as 5.20. This magnitude shows that China highly depends on other countries in its production, especially intermediate goods. Meanwhile, the reduction of import content in Japan is supposed to have been caused by GDP slowdown. As production activities slowed down, the demand for intermediate goods also slowed down. 


\begin{tabular}{|c|c|c|}
\multicolumn{3}{|c|}{ Table 9 } \\
\hline Backward LinkageCoefficients \\
\hline Country & $\mathbf{2 0 0 0}$ & $\mathbf{2 0 1 0}$ \\
\hline Indonesia & 1.72 & 1.87 \\
\hline Malaysia & 1.64 & 1.47 \\
\hline Philippines & 1.50 & 1.69 \\
Singapore & 1.73 & 1.43 \\
\hline Thailand & 1.73 & 2.17 \\
\hline China & 2.57 & 5.20 \\
Taiwan & 1.73 & 2.17 \\
Korea & 1.95 & 2.38 \\
\hline Japan & 2.46 & 1.81 \\
\hline U.S.A. & 2.19 & 2.32 \\
\hline
\end{tabular}

\begin{tabular}{|c|c|c|}
\hline \multicolumn{3}{|c|}{ Tabel 10 } \\
\hline Forward Linkage Coefficients \\
\hline Country & $\mathbf{2 0 0 0}$ & $\mathbf{2 0 1 0}$ \\
\hline Indonesia & 1.74 & 1.85 \\
Malaysia & 2.01 & 1.75 \\
Philippines & 1.76 & 1.83 \\
Singapore & 1.99 & 1.68 \\
Thailand & 1.92 & 2.60 \\
China & 2.48 & 4.66 \\
Taiwan & 1.86 & 2.55 \\
Korea & 1.93 & 2.44 \\
Japan & 1.79 & 1.48 \\
U.S.A. & 1.74 & 1.69 \\
\hline
\end{tabular}

Table 10 shows the forward linkage (FL) coefficients of each country, showing the amount of output produced in domestic which will become an input for production in other countries (export of intermediate goods). From FL coefficient, Indonesia experienced an increase in the export of intermediate goods from 1.74 in 2000 to 1.85 in 2010. Such an increase also occurs in other South Asian countries such as Philippines and Thailand.

In the meantime, China that had the highest FL coefficient in 2000, that is, 2.48, experienced a rapid increase in FL coefficient in 2010, which was up to 4.66. It shows that China is not only highly dependent on intermediate goods but also has large exports of intermediate goods.

International trade becomes the world's main source of economic growth. The pattern of economic relationships and linkages between countries are influenced by various factors, one of which is the trade channel. The world trade value calculated from the ratio of total exports and imports of goods towards GDP shows an increasing trend from about 37\% in 1980 to more than $51.5 \%$ in 2011 (Graphic 1). These indicators show that the degree of the world economic openness in general resulted in increasingly open and interconnected development.

Developed countries still have a larger share in external trade than those of other countries. Meanwhile, despite having a relatively small portion, developing countries in Asia show an accelerated growth compared to other regions. The share of exports and imports in growing region of Asia to world GDP rose significantly to 9\%, or nearly 5 times higher than in 1980. The largest contribution to the rise was China, while the moderate size in contribution sourced from India, Malaysia, Thailand, and Indonesia. 


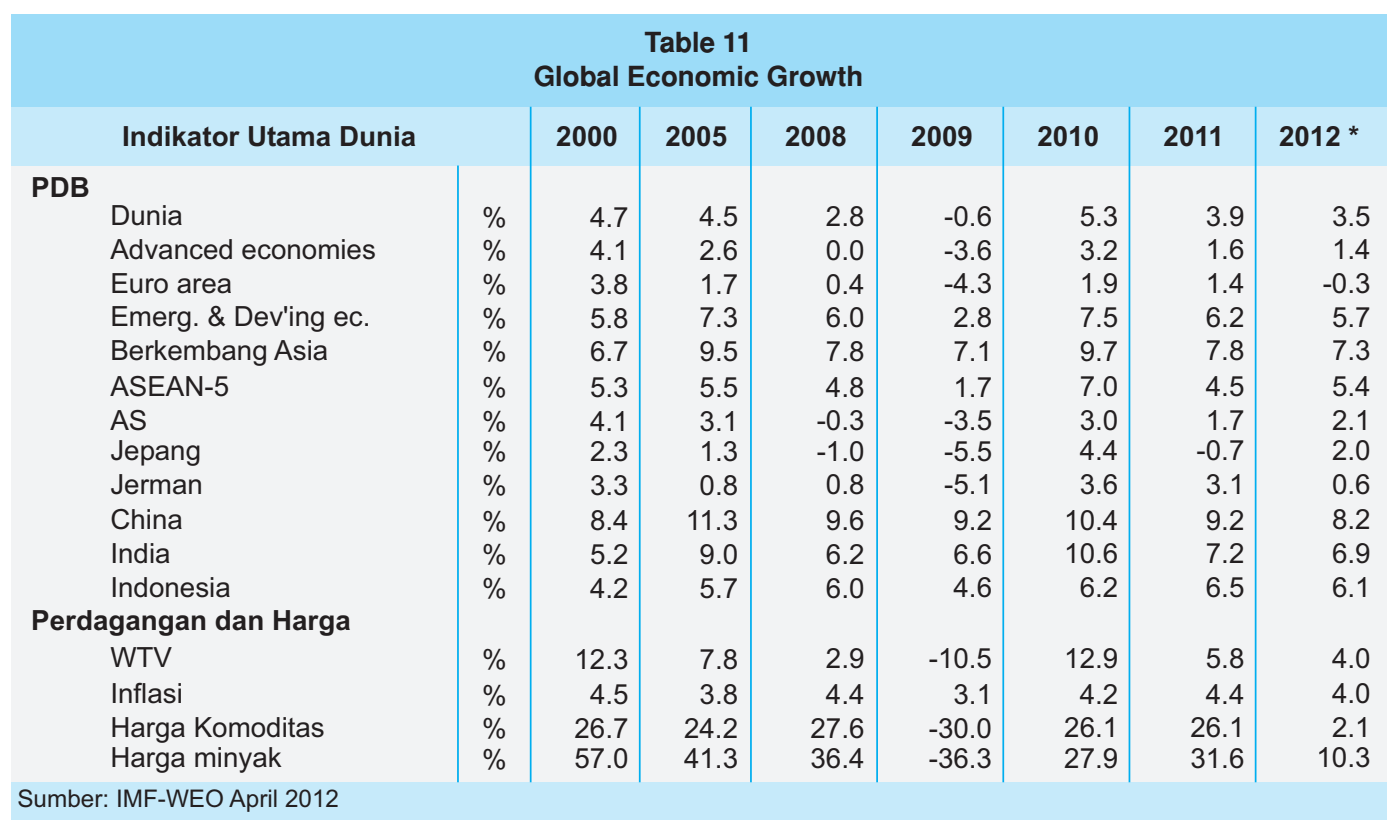

Although the role of China's international trade was growing rapidly, the composition ratio of exports and imports to China's GDP was not too big. The ratio of exports and imports to GDP in 2011 was approximately 50\%, or well below countries such as Singapore (298\%), Malaysia (149\%) (Graphic 2). This was in line with the typical country with a large population characterized by the role of domestic demands, which was more prominent. India, U.S., and Indonesia respectively had degrees of openness ratio of $44.5 \%, 24.8 \%$, and $44.7 \%$. World economic cycle sourced mainly from developed countries, has great potential to be transmitted

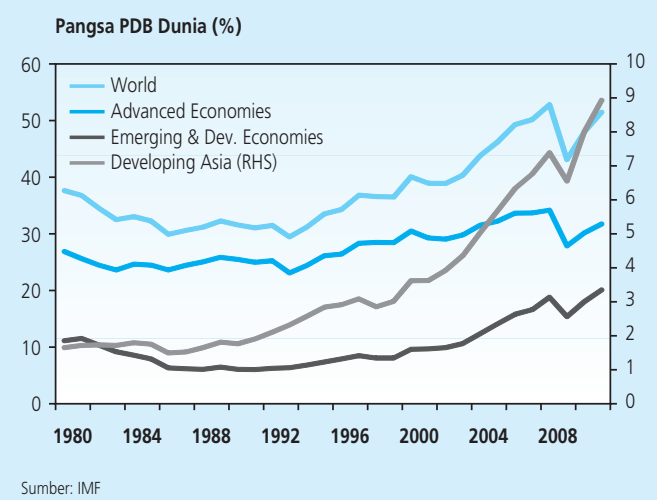

Graphic 1. Growth in International Trade Ratio per Region (\% GDP)

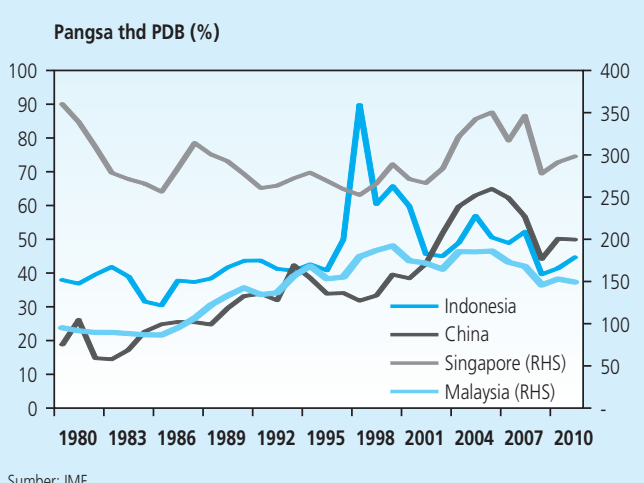

Graphic 2. Growth in International Trade Ratio per GDP vs Rating 
larger to the country with a relatively higher degree of economic openness ratio. Referring to Chinese economic data, the transmission potential is relatively modest compared to Singapore for instance.

As an example, Table 11 shows that, despite the country's GDP in developed countries, both in the U.S. and the Euro area with contraction in 2009, China's economic growth remains high at $9.2 \%$ (Graphic 3). GDP structure which leans towards domestic sources such as investment and consumption becomes the downfall retaining bumper export (external demands). Similar structures are also found in the economy of India and Indonesia, which recently grows each of $6.6 \%$ and $4.6 \%$ respectively (Graphic 4). In about 2009 and 2010 , many assessments were conducted in linking economic decoupling phenomenon in Asia and China as the new global economy driver.

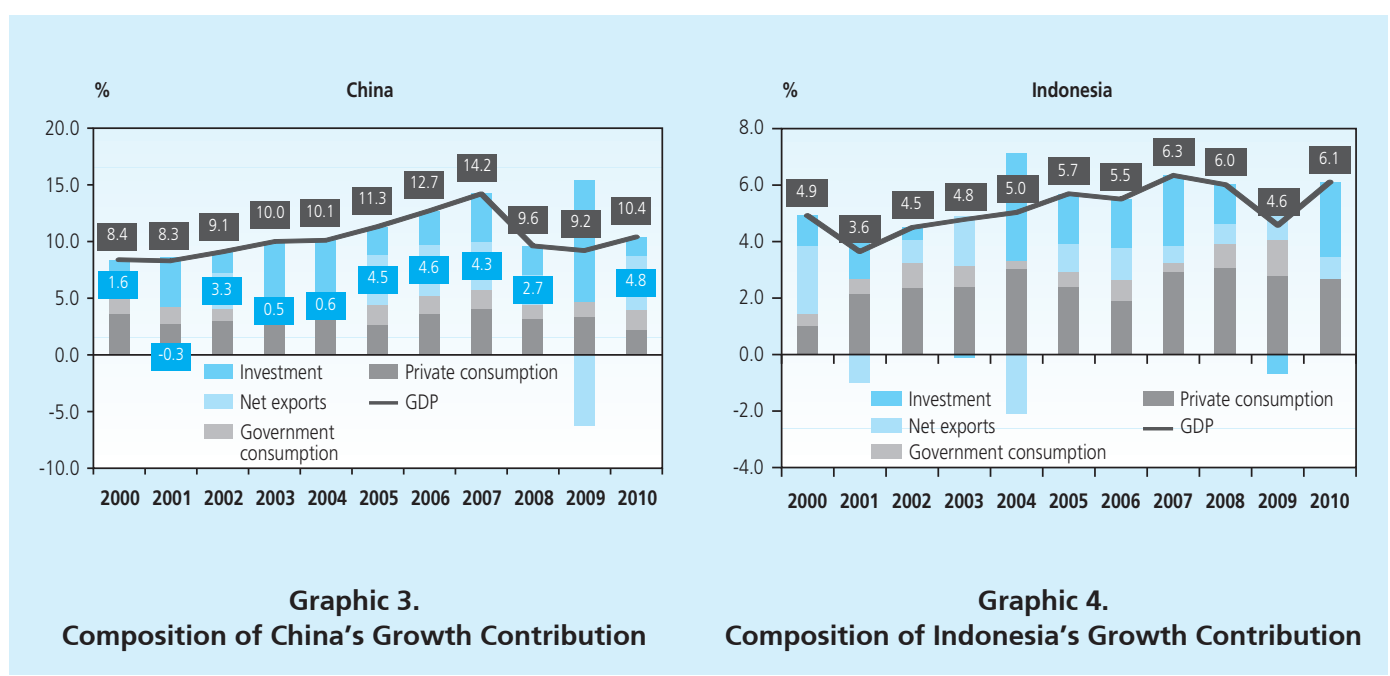

Both results from calculated coefficient conforms the above description. We can extend our analysis by examining the bilateral relation as provided in Table 12 and Table 13. Until 2010, the production network in Asia has significantly changed. The green and yellow cells in Table 12 reflect strong connection among countries; while the red and the orange cells reflect weak connection. The table conform the strong linkages between Asian countries including Indonesia, to developed ones such as Japan and USA.

For 2010 condition, there were two interesting points, first, supplier is highly concentrated in Asian countries. Recently, all countries in Asia including US and Japan use intermediate output from China, followed by Korea, Japan, and Singapore. Second, dependency on the main supplier has shifted; previously, it relied much on Japan and the US, but it is now on China. It is not only due to economic growth, particularly Chinese high manufacturing sector, but also 
because some companies in the US and Japan relocated their factories to the country of their target market; consequently, their exports and imports of goods in a country are no longer through international trade.

Indonesia has a relatively weak production network with other countries. However, at present, Indonesia has a wider linkage. In 2000, Indonesia had stronger linkage to her neighboring countries like Malaysia and Singapore, and in 2010, Indonesia's input was strongly linked to Taiwan and Korea.

\begin{tabular}{|c|c|c|c|c|c|c|c|c|c|c|c|}
\hline \multicolumn{12}{|c|}{$\begin{array}{c}\text { Table } 12 \\
\text { The Linkage of Asian IO among Countries In } 2000\end{array}$} \\
\hline \multicolumn{12}{|c|}{ USER } \\
\hline \multirow{11}{*}{ 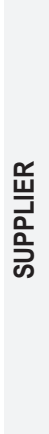 } & & Indonesia & Malaysia & Philippines & Singapore & Thailand & China & Taiwan & Korea & Japan & U.S.A. \\
\hline & Indonesia & & 0.018 & 0.011 & 0.015 & 0.011 & 0.004 & 0.010 & 0.011 & 0.004 & 0.001 \\
\hline & Malaysia & 0.009 & & 0.017 & 0.082 & 0.022 & 0.005 & 0.015 & 0.009 & 0.003 & 0.002 \\
\hline & Philippines & 0.001 & 0.013 & & 0.003 & 0.004 & 0.001 & 0.007 & 0.002 & 0.001 & 0.001 \\
\hline & Singapore & 0.007 & 0.095 & 0.029 & & 0.021 & 0.005 & 0.014 & 0.006 & 0.001 & 0.002 \\
\hline & Thailand & 0.006 & 0.035 & 0.013 & 0.023 & & 0.004 & 0.008 & 0.003 & 0.002 & 0.001 \\
\hline & China & 0.017 & 0.039 & 0.018 & 0.046 & 0.035 & & 0.024 & 0.028 & 0.008 & 0.006 \\
\hline & Taiwan & 0.007 & 0.043 & 0.021 & 0.021 & 0.019 & 0.023 & & 0.009 & 0.004 & 0.003 \\
\hline & Korea & 0.013 & 0.036 & 0.034 & 0.026 & 0.020 & 0.026 & 0.030 & & 0.005 & 0.004 \\
\hline & Japan & 0.031 & 0.148 & 0.087 & 0.133 & 0.102 & 0.039 & 0.104 & 0.057 & & 0.011 \\
\hline & U.S.A. & 0.021 & 0.113 & 0.065 & 0.090 & 0.048 & 0.020 & 0.060 & 0.051 & 0.014 & \\
\hline
\end{tabular}

\begin{tabular}{|c|c|c|c|c|c|c|c|c|c|c|c|}
\hline \multicolumn{12}{|c|}{$\begin{array}{c}\text { Tabel } 13 \\
\text { The Linkage of Asian IO among Countries In } 2010\end{array}$} \\
\hline \multicolumn{12}{|c|}{ USER } \\
\hline \multirow{11}{*}{$\begin{array}{l}\text { 吕 } \\
\frac{\vec{a}}{\frac{0}{丂}} \\
\text { ๘ }\end{array}$} & & Indonesia & Malaysia & Philippines & Singapore & Thailand & China & Taiwan & Korea & Japan & U.S.A. \\
\hline & Indonesia & & 0.019 & 0.011 & 0.016 & 0.027 & 0.011 & 0.028 & 0.023 & 0.006 & 0.001 \\
\hline & Malaysia & 0.006 & & 0.010 & 0.051 & 0.031 & 0.007 & 0.024 & 0.011 & 0.002 & 0.001 \\
\hline & Philippines & 0.001 & 0.020 & & 0.004 & 0.014 & 0.005 & 0.028 & 0.007 & 0.002 & 0.002 \\
\hline & Singapore & 0.004 & 0.046 & 0.013 & & 0.023 & 0.005 & 0.017 & 0.006 & 0.001 & 0.001 \\
\hline & Thailand & 0.006 & 0.032 & 0.011 & 0.021 & & 0.008 & 0.019 & 0.006 & 0.002 & 0.001 \\
\hline & China & 0.043 & 0.085 & 0.038 & 0.101 & 0.178 & & 0.138 & 0.121 & 0.024 & 0.014 \\
\hline & Taiwan & 0.007 & 0.036 & 0.017 & 0.017 & 0.036 & 0.042 & & 0.015 & 0.004 & 0.003 \\
\hline & Korea & 0.014 & 0.033 & 0.030 & 0.024 & 0.041 & 0.051 & 0.069 & & 0.006 & 0.003 \\
\hline & Japan & 0.013 & 0.053 & 0.030 & 0.047 & 0.082 & 0.031 & 0.095 & 0.040 & & 0.004 \\
\hline & U.S.A. & 0.022 & 0.103 & 0.057 & 0.082 & 0.100 & 0.042 & 0.141 & 0.093 & 0.017 & \\
\hline
\end{tabular}


The results of calculate $\mathrm{BL}$ and $\mathrm{FL}$ coefficient have some implications particularly for Indonesia. Indonesia's production is sustained by external and domestic trade, but the activities did not effectively create value added because Indonesia tends to export intermediate instead of final goods. With those characteristics, Indonesia's exporting performance is prone to the production or demand fluctuation from her trading partners.

\subsection{Aggregate AIO: Dependency Rate of Value Added}

In the previous analysis (BL and $\mathrm{FL}$ ), the relation among countries were only limited to the flow of intermediate goods. This section analyzes the contribution and the impact of final demand towards the value added. The calculation result is provided on the following table.

\begin{tabular}{|c|c|c|}
\hline \multicolumn{3}{|c|}{$\begin{array}{l}\text { Table } 14 \\
\text { The Contribution of Final Demand to Value Added } 2010\end{array}$} \\
\hline \multicolumn{3}{|c|}{ Table (a) The Impact Final Demand on Value Added, Indonesia } \\
\hline & 2000 & 2010 \\
\hline Domestic Demand & $90.3 \%$ & $91.4 \%$ \\
\hline South East Asia Trade & $1.2 \%$ & $1.4 \%$ \\
\hline Japan & $2.2 \%$ & $2.3 \%$ \\
\hline Cina & $2.4 \%$ & $1.8 \%$ \\
\hline AS & $2.1 \%$ & $1.9 \%$ \\
\hline \multicolumn{3}{|c|}{ Table (b) The Contribution of Final Demand to Value Added, China } \\
\hline & 2000 & 2010 \\
\hline Domestic Demand & $93.2 \%$ & $87.6 \%$ \\
\hline South East Asia Trade & $1.0 \%$ & 2. $1 \%$ \\
\hline Japan & $1.3 \%$ & $2.9 \%$ \\
\hline AS & $1.6 \%$ & $3.1 \%$ \\
\hline
\end{tabular}

The calculation in Table 14 show that Indonesia is highly depends on domestic demand. In 2000, the dependency rate towards domestic demand is $90.3 \%$ while in 2010is $91.4 \%$. This amount is in line with the increase of Indonesia's domestic consumption as source of the economic growth. On the other hand, Indonesia's linkage with external trade is relatively decreasing especially for goods under final demand category. Final demand goods are commonly used in South East Asia and the scale continues to rise across the two years (from $1.2 \%$ to $1.4 \%$ ). The table above also show the export of Indonesia is mostly intermediate goods. 
As the comparison, from the same table, China shows a trade pattern in which it acts as the main supplier. Although the role of domestic demand to value added of China is still relatively high ( $87.6 \%$ in 2010 ), the scale tends to decline if compared with that in 2000 . The role of domestic demand which continues to decline is replaced by final demand trade from other countries. The largest growth of final demand exports is between China and developed country: the USA. Therefore, every change in final demand of that country will greatly affect China's value added. This calculation confirms that China as the main supplier does not operate only for intermediate goods but also the final ones.

Nevertheless, economy more directed to domestic is not without risk. The development of industrial sector for strong domestic demands remains a major capital. Under the condition when international trade competition intensifies, flow of cheap goods from abroad can easily enter and compete with the domestic industries. Therefore, if the competitiveness of domestic production is inferior to other countries, there will be a flood of imported goods, especially consumer goods. In addition, strategies which are too domestic-oriented will be left behind in exploiting the momentum of global economic growth at the time of recovery and high growth.

\subsection{AIO Sectors: Backward Linkages and Forward Linkages}

Another important thing that becomes focus of analysis is the strong linkage of sectors in Indonesia with the world production chain. Aggregate data cannot accommodate heterogeneity data. By using RAS, iteration was conducted to get sectoral numbers. The result of $\mathrm{BL}$ and $\mathrm{FL}$ in sectoral side can be seen on Table 15 and Table 16.

\begin{tabular}{|c|c|c|}
\hline \multicolumn{3}{|c|}{$\begin{array}{c}\text { Table } 15 \\
\text { Backward Linkages of Main Sector in Indonesia }\end{array}$} \\
\hline Backward Linkages - Sector & 2000 & 2010 \\
\hline Trade and transport & 3.74 & 4.31 \\
\hline Crude petroleum and natural gas & 3.50 & 4.28 \\
\hline Services & 2.77 & 3.16 \\
\hline Other mining & 2.12 & 2.40 \\
\hline Food, beverage and tobacco & 2.02 & 2.21 \\
\hline Chemical products & 1.95 & 2.12 \\
\hline Other agricultural products & 1.74 & 1.90 \\
\hline Transport equipment & 1.73 & 1.89 \\
\hline Pulp, paper and printing & 1.59 & 1.72 \\
\hline Metal products & 1.58 & 1.70 \\
\hline
\end{tabular}




\begin{tabular}{|c|c|c|}
\hline \multicolumn{3}{|c|}{$\begin{array}{c}\text { Tabel } 16 \\
\text { Forward Linkages of Main Sector in Indonesia }\end{array}$} \\
\hline Forward Linkages -Sector & 2000 & 2010 \\
\hline Textile, leather, and the products thereof & 2.07 & 2.13 \\
\hline Timber and wooden products & 1.97 & 2.08 \\
\hline Electricity, gas, and water supply & 1.95 & 2.08 \\
\hline Food, beverage and tobacco & 1.97 & 2.07 \\
\hline Construction & 1.97 & 2.05 \\
\hline Metal products & 2.00 & 2.04 \\
\hline Other manufacturing products & 2.03 & 2.02 \\
\hline Transport equipment & 1.94 & 2.01 \\
\hline Livestock and poultry & 1.85 & 1.98 \\
\hline Machinery & 2.01 & 1.96 \\
\hline
\end{tabular}

The result showed that in 2000 sectors that had the strongest backward linkages were Trade and Transport Sector (4.31) and Crude Petroleum and Natural Gas Sector (4.28). The two sectors also experienced an increasing import needs in 2010 relative to 2000 . On the other hand, sectors that had the highest forward linkages (export intermediate good) in 2010 was Textile, Leather, and the Products Thereof Sector (2.13) followed by Timber and Wooden Products Sector (2.08).

There is one interesting thing on machinery sector. In 2000, machinery had the highest forward linkages, but in 2010, it decreased. This was possibly due to the use of intermediate goods such as machinery to fulfill domestic needs instead of export. This was in line with the increasing rate of Indonesia's investment that needs larger amount of capital goods.

Sector that had the highest BL, Trade and Transport Sector, had the highest import linkage with China; while the largest FL for this sector (intermediate good export) is with United States. On the other hand, Textile, Leather, and the Products Thereof Sector had the biggest import content with Malaysia; while it's highest FL is with Korea and United States.

We can confront the calculation on BL and FL above with Grubel-Lloyd index (GL), which enables us to see the characteristics of international trade of a country. Grubel-Lloyd index was firstly introduced in 1975. The formula in the index compares the export and import of goods of similar types (groups), as can be seen in the following formula:

$$
G L_{\text {sector } i}=1-\left\{\frac{\mid \text { ekspor }_{\text {sector i }}-\text { impor }_{\text {sector } \mathrm{i}} \mid}{\text { ekspor }_{\text {sector } \mathrm{i}}+\text { impor }_{\text {sector } \mathrm{i}}}\right\}
$$

If a country only exports and imports goods of the same types (groups of goods) and the same quantity, the GL index is equal to 1 . Meanwhile, if a country only exports and imports 
particular commodities, the GL index is 0 . Therefore, the index varies between 0 (indicating pure inter-industry trade) and 1 (intra-industry trade).

The tendency of GL index to be zero (0) indicates that chain of production linkage either bilateral or multilateral remains strong, in the sense more susceptible to the world's economy cycle. ASEAN countries with the highest index in 2010 were Singapore (0.8), Thailand and Malaysia (approximately 0.7 ). Meanwhile, Indonesia and China had relatively low GL index of around 0.5 (Graphic 7). Using the same graph, we see the index for most of the countries increase between the two years. This supports the hypothesis of more countries improve their international trade orientation. Although not being formally tested, the tendency to have high or low index is likely depending on economic openness.

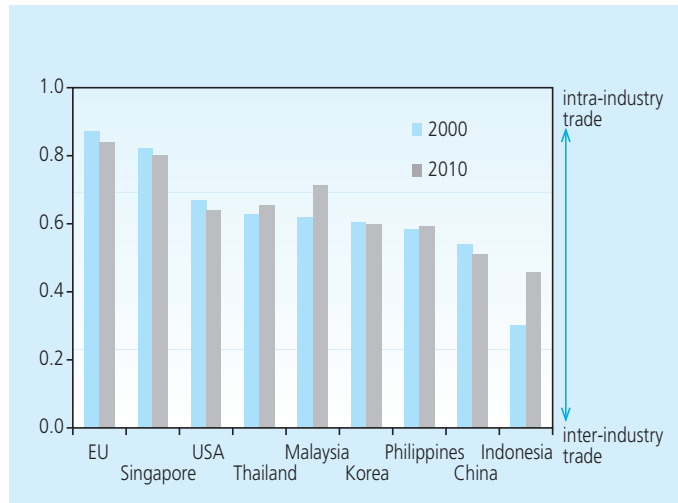

Graphic 5.

GL Index of Several Countries

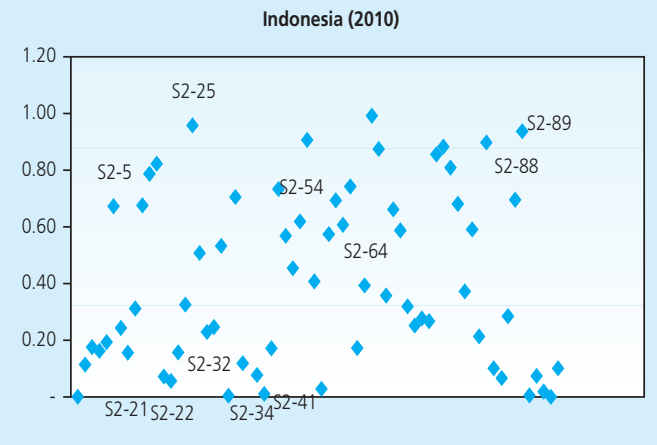

Graphic 6.

GL Index of Indonesia per Commodity

For Indonesia, the distribution of index per commodities piles up in below 0.5 areas (Graphic 6). Commodities above the average index include Pulp, Machinery equipment, Textile products, and Thread. Primary products traded internationally by Indonesia such as Livestock, Crude palm oil, Coal and Fuel tend to have zero index.

The analysis of GL index was also conducted to see the pattern of bilateral trade. Based on the bilateral trade data, Indonesia's trade partners such as Thailand, Malaysia, and Korea have a relatively high index (Graphic 7). The pattern of commodity distribution across trading partners is available on Graphic 8. 


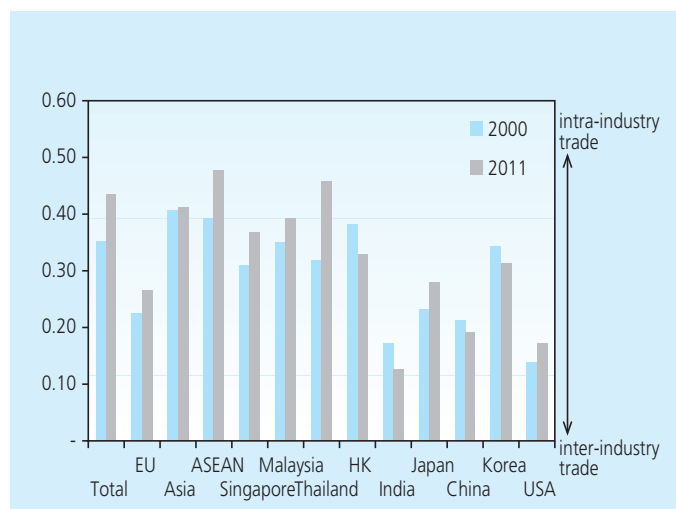

Graphic 7. GL Index on Indonesia's Bilateral Trade with Major Business Partners
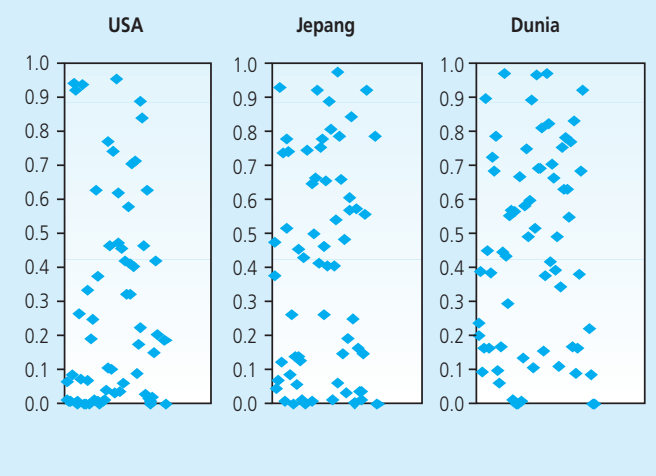

\section{Graphic 8. Indonesia's Trading Partners with} Developed Countries and the World

\subsection{The Simulation of United States Slowdown}

In 1980, the United States was very dominant within the global trade with $12 \%$ contribution, followed by Japan with $6.7 \%^{5}$. Along with China's impressive growth in the last decade, the contribution of US on the world market reduced to $10.4 \%$, while China recorded 10.2\% in 2011 and 4.7\% for Japan, (IMF-WEO April 2012).

Global economic downturn in 2009 triggered by the United States became one of the reasons behind the economic slowdown of other regions. The ongoing crisis had feared developing countries over significant impact on their domestic economy. In 2009, the global economy dropped to $0.6 \%$ mainly due to the growth decrease in developed countries which amounted to 3.6\%. Meanwhile, developing countries particularly in Asia were still capable to grow up to $7.1 \%$. The remaining strong growth of Asian countries strengthened various allegations whether Asian economics had experienced a decoupling with the U.S. economy. Off this concern we provide quantitative simulation below.

We use the AIO table to simulate the impact of $1 \%$ reduction of United States GDP on other countries. In this simulation, the impact on whole countries in this region and the impact between 2010 and 2000 will be compared.

5 World trade contribution is calculated from the total exports plus imports in one country divided by total exports plus imports of the world. 


\begin{tabular}{|c|c|c|c|c|c|}
\hline \multicolumn{6}{|c|}{$\begin{array}{l}\text { Table } 17 \\
\text { The Impact of Deceleration of US GDP on GDP of Countries on that Region (\%) }\end{array}$} \\
\hline & \multicolumn{2}{|c|}{ Th. 2000} & \multicolumn{2}{|c|}{ Th. 2010} & \multirow{2}{*}{$\begin{array}{r}(4) /(2) \\
\text { Ratio }\end{array}$} \\
\hline & Direct Impact & Total Impact & Direct Impact & Total Impact & \\
\hline Country & (1) & $(2)$ & (3) & (4) & $(5)$ \\
\hline Indonesia & -0.054 & -0.097 & -0.018 & -0.046 & 0.48 \\
\hline Malaysia & -0.121 & -0.180 & -0.061 & -0.131 & 0.73 \\
\hline Philippines & -0.098 & -0.168 & -0.068 & -0.162 & 0.96 \\
\hline Singapore & -0.092 & -0.136 & -0.038 & -0.090 & 0.66 \\
\hline Thailand & -0.074 & -0.125 & -0.032 & -0.101 & 0.81 \\
\hline Cina & -0.056 & -0.102 & -0.025 & -0.128 & 1.25 \\
\hline Taiwan & -0.077 & -0.131 & -0.042 & -0.136 & 1.04 \\
\hline Korea & -0.051 & -0.092 & -0.026 & -0.082 & 0.89 \\
\hline Japan & -0.029 & -0.057 & -0.014 & -0.033 & 0.58 \\
\hline
\end{tabular}

The slowdown of United States economy also reduced other economies except to China and Taiwan. For Indonesia, the impact in 2010 is smaller than in 2000. A one percent reduction on US economy would cause deceleration of Indonesia's GDP for about 0.046\% in 2010. Compared to 2000 , the impact was $0.097 \%$, which is in line with the decreasing rate of non-oil products export from Indonesia to United States from 16.8\% in 2000 to $9.6 \%$ in 2011.

The impact of United States slowdown on Taiwan was constant between 2000 and 2010. From simulation result, a $1 \%$ reduction of United States GDP will decelerate Taiwan's GDP by $0.136 \%$ in 2010 , and is almost the same as in 2000 of $0.131 \%$. This is reasonable considering the harmonic traditional relationship between the two countries. According to their bilateral trade data, 12\% of Taiwan's export goes to United States, which put United States as the second largest export destination.

Meanwhile, the impact of United States slowdown on China increased significantly between the two periods. The impact of United States slowdown on China in 2010 increased about $125 \%$ compared to 2000 . In 2010, China's GDP would decelerate by $0.128 \%$ if United States GDP decelerated by $1 \%$. For 2000 , the impact was $0.102 \%$. This was in line with the fact that United States was the main export destination for China, amounting to $17.7 \%$ of his total export in 2010. The growing linkage between China and United States was initiated by participation of China in WTO in 2001 and the removal of multi-fiber arrangement by United States in 2005. The simulation conform that China has high dependency to United States economic performance. 
The sectoral impact of the United States slowdown on Indonesia is provided on Table 18. Textile, Leather, and the Products there of experience the largest impact. If United States GDP decelerated by $1 \%$, then Textile, Leather, and the Products There of Sector will decelerate about $0.0062 \%$. This is in line with textile export destination to US, which amounting to 33\% of the total Indonesia's textile export in 2012 (January-May).

\begin{tabular}{l|c|}
\hline \multicolumn{2}{|c|}{ Tabel 18 } \\
The Impact of Deceleration US GDP to Sectoral GDP in Indonesia (\%) \\
\multicolumn{1}{|c|}{ Sektor } & $\mathbf{2 0 1 0}$ \\
& Total Impact \\
\hline Textile, leather, and the products thereof & -0.0062 \\
Rubber products & -0.0046 \\
Machinery & -0.0040 \\
Timber and wooden products & -0.0034 \\
Forestry & -0.0028 \\
\hline
\end{tabular}

\subsection{The Simulation of Export Slowdown to EU}

This section assesses the impact of export reduction of US and Asian countries to Europe (EU). The magnitude of the shock to simulate is 1 percent of the corresponding exporting countries within the AIO. We will analyze and compare the magnitude of the impact between 2000 and 2010. For Indonesia, we outline the simulation result across sectors.

Table above showed that the impact of export slowdown to EU varied across the two periods. The impact for Indonesia in 2010 decreased by $15 \%$ compared to 2000 . When export to EU decelerated by $1 \%$, the Indonesia's GDP would decelerate by $0.073 \%$ in 2010 , and by $0.086 \%$ in 2000 . This was in line with the decrease of non-oil export from Indonesia's to EU; $18.0 \%$ in 2000 to $12.4 \%$ in 2011.

Meanwhile, China experienced the biggest impact of export deceleration to EU. The impact of changing EU's economic performance to China in 2010 increased almost 10 times compared to 2000. The simulation showed that if the export to EU decelerated by $1 \%$, it would decelerate China's GDP by $0.571 \%$ in 2010 , which is much larger than the impact in 2000 of $0.057 \%$. This was in line with the increasing rate of export performance from China to EU from $16 \%$ in 2000 to $24 \%$ in 2010 . The rapid increasing linkage between China and 


\begin{tabular}{|c|c|c|c|c|c|}
\hline \multicolumn{6}{|c|}{$\begin{array}{l}\text { Tabel } 19 \\
\text { The Impact of Export Slowdown to EU on GDP of Countries on that Region (\%) }\end{array}$} \\
\hline & \multicolumn{2}{|c|}{ Th. 2000} & \multicolumn{2}{|c|}{ Th. 2010} & \multirow{2}{*}{$\begin{array}{l}(4) /(2) \\
\text { Rasio }\end{array}$} \\
\hline & Direct Impact & Total Impact & Direct Impact & Total Impact & \\
\hline Country & (1) & $(2)$ & (3) & (4) & (5) \\
\hline Indonesia & -0.048 & -0.086 & -0.037 & -0.073 & 0.85 \\
\hline Malaysia & -0.098 & -0.151 & -0.065 & -0.121 & 0.80 \\
\hline Philippines & -0.067 & -0.115 & -0.039 & -0.114 & 0.99 \\
\hline Singapore & -0.083 & -0.124 & -0.056 & -0.127 & 1.02 \\
\hline Thailand & -0.050 & -0.085 & -0.035 & -0.119 & 1.39 \\
\hline Cina & -0.030 & -0.057 & -0.120 & -0.571 & 9.99 \\
\hline Taiwan & -0.058 & -0.099 & -0.062 & -0.238 & 2.40 \\
\hline Korea & -0.040 & -0.072 & -0.047 & -0.164 & 2.28 \\
\hline Japan & -0.017 & -0.033 & -0.013 & -0.039 & 1.18 \\
\hline U.S.A. & -0.016 & -0.031 & -0.015 & -0.041 & 1.35 \\
\hline
\end{tabular}

EU was also partly influenced by participation of China in WTO in 2001. As China increasingly depends on EU, then it is reasonable for China who recently provides additional assistance for EU's economic recovery through IMF.

The sectoral impact for Indonesia is provided on Table 20. Trade and Transport sector experiences the largest impact. A $1 \%$ export reduction to EU will reduce this sector by $0.011 \%$. About 50\% of Indonesia's export to EU goes to Netherlands, Germany and Italy. During 20092011 , the total export to these countries was $21.2 \%, 15.9 \%$, and $13.1 \%$ respectively.

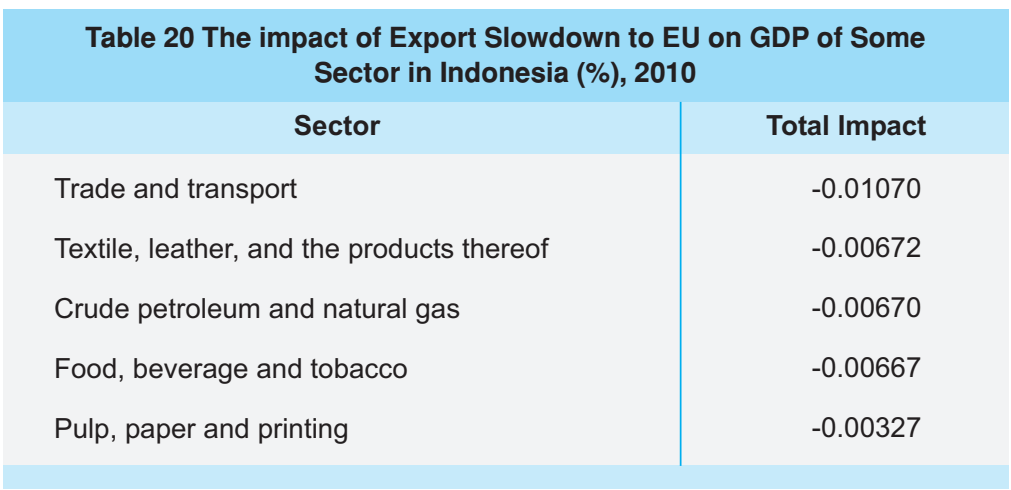




\subsection{The Impact Simulation of China's GDP Slowdown}

This section analyze the impact of $1 \%$ slowdown of China's GDP on the countries within AIO. Table 21 showed the impact generally bigger for 2010 relative to 2000, with the highest increase is for United States.

The impact of China slowdown on Indonesia increased 4 times; a 1\% slowdown of China's GDP will slowdown Indonesia's GDPby $0.140 \%$ in 2010 , and $0.034 \%$ for 2000 . This was in line with the increasing non-oil product export of Indonesia to China, from $3.6 \%$ in 2000 to $13.3 \%$ in 2011 . Therefore, the current trend of the slowing China's economy should be of concern for Indonesia.

\begin{tabular}{|c|c|c|c|c|c|}
\hline \multicolumn{6}{|c|}{$\begin{array}{l}\text { Table } 21 \\
\text { The Impact of China's GDP Slowdown on GDP of Countries on that Region (\%) }\end{array}$} \\
\hline & \multicolumn{2}{|c|}{ Th. 2000} & \multicolumn{2}{|c|}{ Th. 2010} & \multirow{2}{*}{$\begin{array}{r}(4) /(2) \\
\text { Ratio }\end{array}$} \\
\hline & Direct Impact & Total Impact & Direct Impact & Total Impact & \\
\hline Country & (1) & (2) & (3) & (4) & (5) \\
\hline Indonesia & -0.020 & -0.034 & -0.064 & -0.140 & 4.12 \\
\hline Malaysia & -0.035 & -0.055 & -0.102 & -0.182 & 3.34 \\
\hline Philippines & -0.014 & -0.024 & -0.072 & -0.148 & 6.16 \\
\hline Singapore & -0.031 & -0.052 & -0.063 & -0.102 & 1.95 \\
\hline Thailand & -0.020 & -0.033 & -0.046 & -0.093 & 2.79 \\
\hline Taiwan & -0.058 & -0.089 & -0.228 & -0.416 & 4.66 \\
\hline Korea & -0.034 & -0.059 & -0.095 & -0.184 & 3.14 \\
\hline Japan & -0.008 & -0.015 & -0.031 & -0.072 & 4.76 \\
\hline U.S.A. & -0.002 & -0.004 & -0.013 & -0.030 & 7.03 \\
\hline
\end{tabular}

The impact of China slowdown on United States is the largest and significantly increase between the two years. For US, the impact in 2010 is seven times larger than 2000 . A $1 \%$ slowdown of China's economy would decelerate United States GDP by $0.039 \%$ in 2010, and by $0.004 \%$ in 2000 . This was in line with the increasing rate of export performance from United States to China that continuously increase by 542\%; from only USD 16.2 billion in 2000 to USD 103.9 billion in 2011. On the other hand, the export of US to the rest of the world increased by $80 \%$. China is the third largest export destination for United States after Canada and Mexico. The main exported product is agricultural products and high technology products. Our simulation showed that the interdependency between China and United States economy, increase across the two periods. 
The sectoral impact of the slowdown of China's GDP on Indonesia is presented on Table 22. Trade and Transport sector would experience the largest. A $1 \%$ deceleration of China's GDP would decelerate Trade and Transport sector by about 0.0079\%.

\begin{tabular}{|c|c|}
\hline \multicolumn{2}{|c|}{$\begin{array}{c}\text { Table } 22 \text { The Impact of China's GDP Slowdown on GDP } \\
\text { of Some Sectors in Indonesia (\%) }\end{array}$} \\
\hline \multicolumn{2}{|c|}{ Th. 2010} \\
\hline Sector & Total Impact \\
\hline Trade and transport & -0.07886 \\
\hline Food, beverage and tobacco & -0.07870 \\
\hline Construction & -0.05895 \\
\hline Crude petroleum and natural gas & -0.03845 \\
\hline Transport equipment & -0.02632 \\
\hline
\end{tabular}

\subsection{Robustness Check}

We do the robustness check by comparing the consistency of BL coefficient across the numbers of RAS iteration. The result showed that backward linkages on each country has good consistency, see Table 23.

\begin{tabular}{|c|c|c|c|c|c|c|c|c|}
\hline \multicolumn{9}{|c|}{$\begin{array}{c}\text { Table } 23 \\
\text { Backward Linkages and Number of RAS Iteration }\end{array}$} \\
\hline \multirow[t]{2}{*}{ Backward Linkage } & \multicolumn{8}{|c|}{ Number oflteration } \\
\hline & 5 & 10 & 15 & 30 & 50 & 100 & 150 & 200 \\
\hline Indonesia & 1.87 & 1.87 & 1.87 & 1.87 & 1.87 & 1.87 & 1.87 & 1.87 \\
\hline Malaysia & 1.46 & 1.47 & 1.47 & 1.47 & 1.47 & 1.47 & 1.47 & 1.47 \\
\hline Philippines & 1.69 & 1.69 & 1.69 & 1.69 & 1.69 & 1.69 & 1.69 & 1.69 \\
\hline Singapore & 1.43 & 1.43 & 1.43 & 1.43 & 1.43 & 1.43 & 1.43 & 1.43 \\
\hline Thailand & 2.15 & 2.17 & 2.17 & 2.17 & 2.17 & 2.17 & 2.17 & 2.17 \\
\hline Cina & 5.14 & 5.18 & 5.20 & 5.20 & 5.20 & 5.20 & 5.20 & 5.20 \\
\hline Taiwan & 2.14 & 2.16 & 2.16 & 2.17 & 2.17 & 2.17 & 2.17 & 2.17 \\
\hline Korea & 2.36 & 2.38 & 2.38 & 2.39 & 2.38 & 2.38 & 2.38 & 2.38 \\
\hline Japan & 1.82 & 1.82 & 1.82 & 1.81 & 1.81 & 1.81 & 1.81 & 1.81 \\
\hline U.S.A. & 2.24 & 2.28 & 2.30 & 2.32 & 2.32 & 2.32 & 2.32 & 2.32 \\
\hline
\end{tabular}


Another way to do the robustness test is by comparing our result with previous studies. Estimation conducted by IMF staff using AIO 1995 and 2010 showed similar Backward Linkage mapping. In general they also found that all AIO countries experience stronger linkage with China, while their linkage with Japan decreased.

Another study from IMF staff analyzed the sensitivity of Asia's export to China. This study showed that commodity export (intermediate goods) from Indonesia are more sensitive compared to manufactured export (generally final goods), see Table 25. This was in line with our paper where the export of Indonesia's contributed less on value added. Moreover, the commodity exported from Indonesia was mainly used for China's domestic demand, and not for exporting.

Table 24

Map of Trade Relationship Among Countries

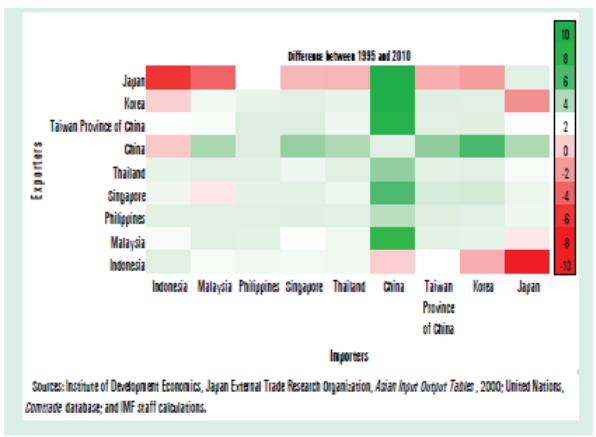

Table 25

Asia Export Determinant to China

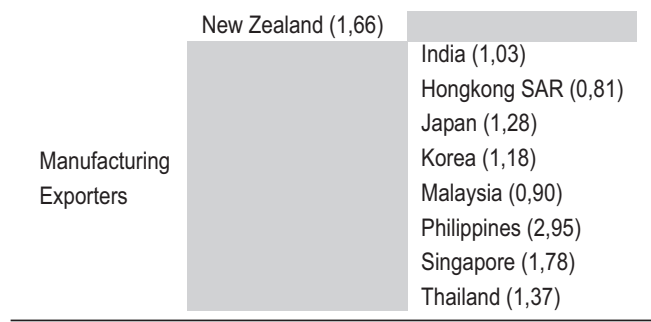

Source : IMF Staff Estimates

${ }^{1}$ Numbers in parentheses denote elasticity of exports to China at 5 percent level of significance. Shaded areas indicate no significance at 5 percent level.

\section{CONCLUSIONS}

This paper used Asian Input Output table to analyze the impact of a shock from one country to another, transmitted via international trade. Our calculation shows the impact of economic slowdown of United States and EU on other countries decrease between 2000 and 2010. Meanwhile the impact of China economic slowdown increases across the two years of observation.

For Indonesia, the China economic slowdown gives a relatively higher impact than the United States and EU slowdown. The direct impact of 1\% GDP slowdown of United States, EU and China to Indonesia is $-0.018 \%,-0.037 \%$ and $-0.064 \%$ respectively, while the total impact of similar shock is $-0.046 \%,-0.073 \%$, and $-0.140 \%$ respectively.

The impact of economic slowdown from major countries to Indonesia relatively lowers than other countries in ASEAN. This is in line with Indonesia exporting mainly commodity with low value added. Furthermore, the intra-trade industry linkage is still low, while the source of growth for Indonesia mainly comes from domestic demand. 
The above conclusions bring some implications. First, Indonesia should concern more on the long term global weakening and deceleration of China's domestic demand. Second, the low impact for Indonesia does not necessarily mean Indonesia's economy is good. The majority of commodity type on Indonesia's export and the low indicator of ITT show the role of Indonesia in global trade linkage is still low. Therefore, diversification of export product onto high added value one is necessary.

Related to future research, the Input Output method used on this paper is a static model with no behavioral equation. We expect future study will use a more comprehensive analysis such as Computable General Equilibrium (CGE) method, which enable us to internalize the behavior of the observed countries. 


\section{REFERENCES}

Bank Indonesia. Buletin Ekspor Impor Indonesia. Departemen Statistik Ekonomi Moneter, Bank Indonesia, Berbagai Edisi

Buetre and Esfahani (2000). Updating an Input Output Table for Use in Policy Analysis. The Australian Journal of Agricultural and Resource Economics, 44:4, pp.573-603.

Capilit, E (2009). RAS Method. Paper prepared for presentation at the 2nd Data Review Workshop, ADB, 7-12 December 2009

Christ, F. Carl, 1955, A Review of Input-Output Analysis, Volume Title: Input-Output Analysis: An Appraisal, Princeton University Press, http://www.nber.org/books/unkn55-2

Ibrahim, et al. (2010). Dampak ACFTA terhadap Perdagangan Internasional Indonesia. Direktorat Riset Ekonomi and Kebijakan Moneter Bank Indonesia

International Monetary Fund (2012). Regional Economic Outlook: Asia and Pacific Managing Spillovers and Advancing Economic Rebalancing. World Economic and Financial Surveys, International Monetary Fund, April

International Monetary Fund (2012). World Economic Outlook. World Economic and Financial Surveys, International Monetary Fund, April

Iskandar, C.L, and Yanfitri (2011). Keterkaitan Perdagangan AS-EU dengan country Lainnya: Potensi Spill-over Krisisdi develop countries. Catatan Riset No.13/16/DKM/BRE/CR, Biro Riset Ekonomi, Direktorat Riset Ekonomi and Kebijakan Moneter, Bank Indonesia.

Mori, Tomoko and Hitoshi Sasaki (2007). Interpendence of Production and Income in Asia Pasific Economies : An International Input Output Approach. Bank of Japan Working Paper Series No. 07-E-26.

Mun-Heng TOH (1998). Projecting the Leontief inverse directly by the RAS method. Paper prepared for presentation at the 12th International Conference on Input-Output Techniques, New York, 18-22 May 1998

Pula Gabor and Tuomas A Peltonen (2009). Has Emerging Asia Decoupled? An Analysis of Production and TradeLinkages Using The Asian International Input Output Table. Working Paper Series No. 993 European Central Bank. 
APPENDIX 1. ASIAN INTERNATIONAL INPUT OUTPUT (AIO)

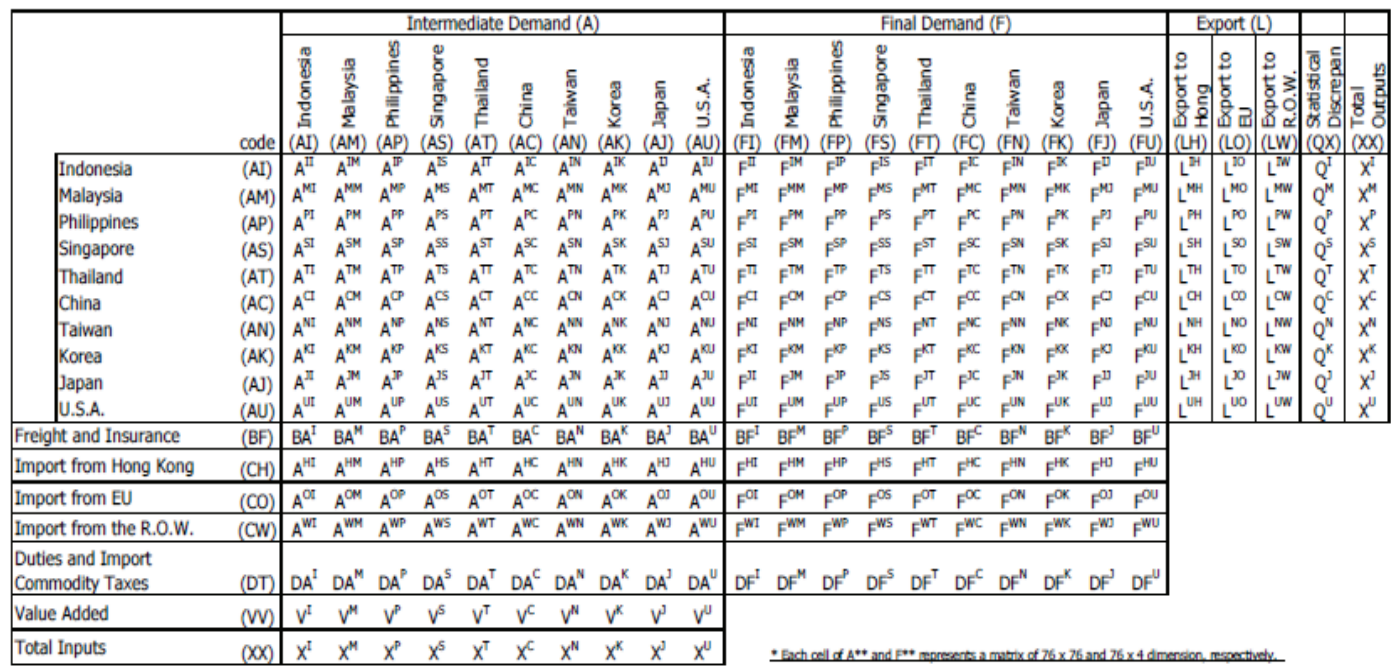

Source: Pula Gabor danTuomas A Peltonen (2009). Has Emerging Asia Decoupled? An Analysis of Production and Trade Linkages Using The Asian International Input Output Table. Working Paper Series No. 993 European Central Bank.

APPENDIX 2. UPDATING TABEL AIO

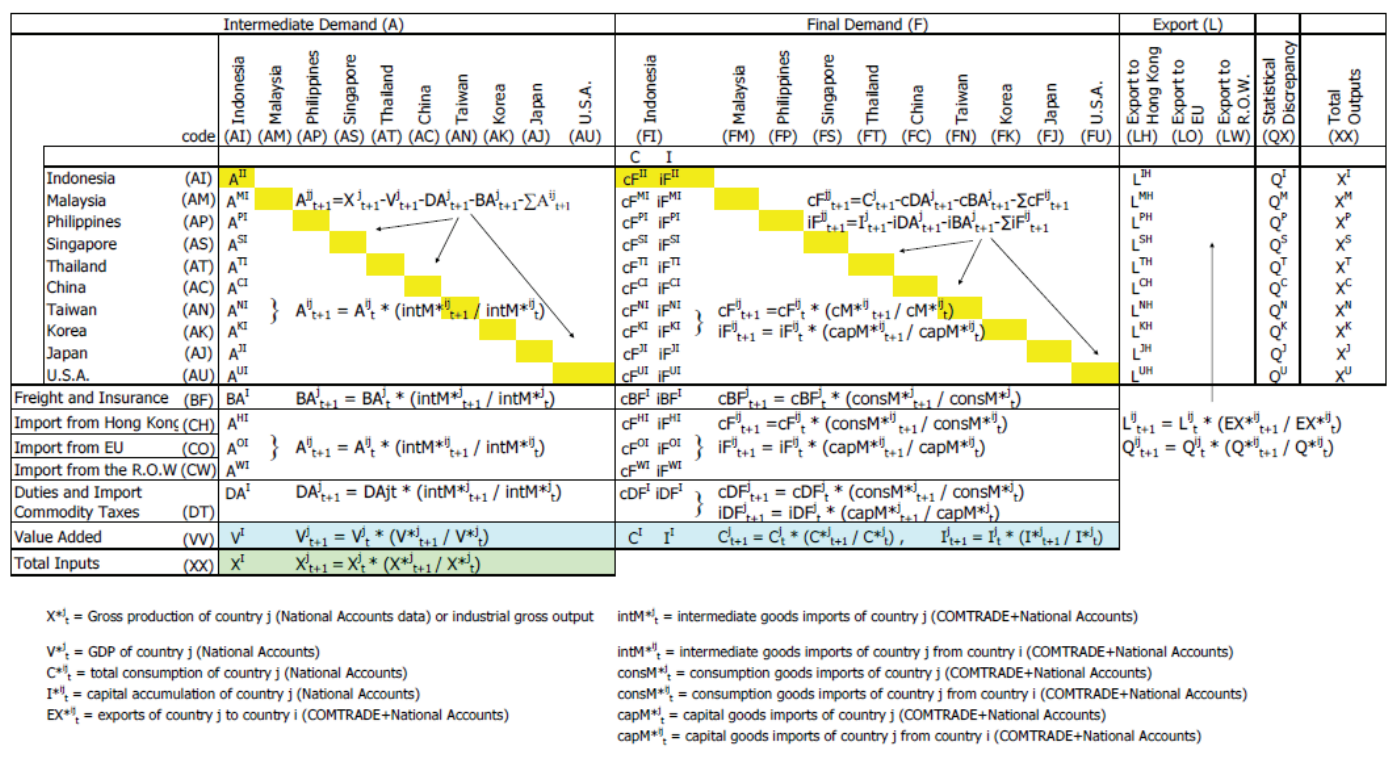

Source: Pula Gabor danTuomas A Peltonen (2009). Has Emerging Asia Decoupled? An Analysis of Production and Trade Linkages Using The Asian International Input Output Table. Working Paper Series No. 993 European Central Bank. 


\section{APPENDIX 3. CONVERSION TABLE, AIO 24 SECTORS}

Sector Classification of 2000 Asian International Input-Output Table

\begin{tabular}{|c|c|c|c|c|c|c|c|}
\hline \multicolumn{2}{|c|}{7 Sector Classification } & \multicolumn{2}{|r|}{24 Sector Classification } & \multicolumn{2}{|r|}{76 Sector Classification } & \multicolumn{2}{|r|}{78 Sector Classification (1995) } \\
\hline \multirow[t]{2}{*}{ Code } & Description & Code & $\begin{array}{c}\text { Description } \\
\end{array}$ & Code & $\begin{array}{c}\text { Description } \\
\end{array}$ & Code & $\begin{array}{c}\text { Description } \\
\end{array}$ \\
\hline & & & Paddy & \multicolumn{4}{|c|}{$\begin{array}{l}\text { INTERMEDIATE SECTORS } \\
\end{array}$} \\
\hline \multirow[t]{11}{*}{001} & \multirow{11}{*}{$\begin{array}{l}\text { Agriculture, } \\
\text { livestock, } \\
\text { forestry } \\
\text { and fishery }\end{array}$} & \multirow{8}{*}{002} & \multirow{8}{*}{ Other agricultural products } & $\frac{001}{002}$ & \begin{tabular}{|l|} 
Paddv \\
Other grain
\end{tabular} & $\frac{001}{1007 \mathrm{~A}}$ & \begin{tabular}{|l} 
Paddv \\
Other grain
\end{tabular} \\
\hline & & & & \multirow[t]{4}{*}{003} & \multirow[t]{4}{*}{ Food crops } & 002 & Cassava \\
\hline & & & & & & 004 & Sugar cane and beet \\
\hline & & & & & & 005 & Oil parm and coconuts \\
\hline & & & & & & $007 \mathrm{~B}$ & Other food crops \\
\hline & & & & \multirow[t]{3}{*}{004} & \multirow[t]{3}{*}{ Non-food crops } & 003 & Natural rubber \\
\hline & & & & & & 006 & Fiber crops \\
\hline & & & & & & 008 & Other commercial crops \\
\hline & & 003 & Livestock and poultry & 005 & Livestock and poultry & 1009 & Livestock and poultry \\
\hline & & 004 & Forestry & 006 & Forestry & 1010 & Forestry \\
\hline & & 005 & Fishery & 007 & Fishery & 011 & Fishery \\
\hline \multirow[t]{6}{*}{002} & \multirow{6}{*}{$\begin{array}{l}\text { Mining and } \\
\text { quarrying }\end{array}$} & 006 & Crude petroleum and natural gas & 1008 & Crude petroleum and natural gas & 1012 & Crude petroleum and natural gas \\
\hline & & \multirow[t]{5}{*}{007} & \multirow[t]{5}{*}{ Other mining } & 1009 & Iron ore & $015 \mathrm{~A}$ & Iron ore \\
\hline & & & & \multirow[t]{3}{*}{010} & \multirow{3}{*}{ Other metallic ore } & 013 & Copper ore \\
\hline & & & & & & 014 & Tin ore \\
\hline & & & & & & $015 \mathrm{~B}$ & Other metallic ore \\
\hline & & & & 011 & Non-metallic ore and quarrving & 016 & Non-metallic ore and quarrying \\
\hline \multirow[t]{9}{*}{003} & \multirow[t]{9}{*}{ Manufacturing } & \multirow[t]{9}{*}{008} & \multirow[t]{9}{*}{ Food, beverage and tobacco } & \multirow[t]{2}{*}{012} & \multirow[t]{2}{*}{ Milled grain and flour } & 018 & Milled rice \\
\hline & & & & & & 019 & Other milled grain and flour \\
\hline & & & & 013 & Fish products & $021 \mathrm{~A}$ & Fish products \\
\hline & & & & 014 & Slaughtering, meat products and dairy products & 021B & Slaughtering and meat products \\
\hline & & & & 015 & Other food products & 017 & Oil and fats \\
\hline & & & & & & 020 & Sugar \\
\hline & & & & & & $021 \mathrm{C}$ & Other food products \\
\hline & & & & 016 & Beverage & $022 \mathrm{~A}$ & Beverage \\
\hline & & & & 017 & Tobacco & 1022B & Tobacco \\
\hline
\end{tabular}

CONVERSION TABLE, AIO 24 SECTORS (Cont.)

\begin{tabular}{|c|c|c|c|c|c|}
\hline \multirow[t]{5}{*}{009} & \multirow{6}{*}{ Textile, leather, and the products thereof } & 018 & Spinning & 023 & Spinning \\
\hline & & 019 & Weaving and dyeing & 024 & Weaving and dyeing \\
\hline & & 020 & Knitting & 025 & Knitting \\
\hline & & 021 & Wearing apparel & 026 & Wearing apparel \\
\hline & & 022 & Other made-up textile products & 027 & Other made-up textile products \\
\hline & & 023 & Leather and leather products & 028 & Leather and leather products \\
\hline \multirow[t]{3}{*}{010} & \multirow[t]{3}{*}{ Timber and wooden products } & 024 & Timber & 029 & Timber \\
\hline & & 025 & Wooden furniture & $030 \mathrm{~A}$ & \begin{tabular}{|l|l|l} 
Furniture \\
\end{tabular} \\
\hline & & 026 & Other wooden products & 1030B & Other wooden products \\
\hline \multirow[t]{2}{*}{011} & \multirow[t]{2}{*}{ Pulp, paper and printing } & 027 & Pulp and paper & 031 & Pulp and paper \\
\hline & & 028 & Printing and publishing & 032 & Printing and publishing \\
\hline \multirow[t]{5}{*}{012} & \multirow[t]{5}{*}{ Chemical products } & 029 & Synthetic resins and fiber & $033 \mathrm{~A}$ & Synthetic resins and fiber \\
\hline & & 030 & Basic industrial chemicals & $033 \mathrm{~B}$ & Other basic industrial chemicals \\
\hline & & 031 & Chemical fertilizers and pesticides & 034 & Chemical fertilizers and pesticides \\
\hline & & 0.32 & Drugs and medicine & $035 \mathrm{~A}$ & Drugs and medicine \\
\hline & & 033 & Other chemical products & 1035B & Other chemical products \\
\hline 013 & Petroleum and petro products & 034 & Refined petroleum and its products & 1036 & Refined petroleum and its products \\
\hline 019 & Other manufacturing products & 0.355 & Plastic products & 1050A & Plastic products \\
\hline \multirow[t]{2}{*}{014} & \multirow[t]{2}{*}{ Rubber products } & 0.36 & Tires and tubes & 0.37 & Tires and tubes \\
\hline & & 037 & Other rubber products & 038 & Other rubber products \\
\hline \multirow[t]{3}{*}{015} & \multirow[t]{3}{*}{ Non-metallic mineral products } & 0.38 & Cement and cement products & 039 & Cement and cement products \\
\hline & & 039 & Glass and glass products & 1040 & Glass and glass products \\
\hline & & 040 & Other non-metallic mineral products & 041 & Other non-metallic mineral products \\
\hline \multirow[t]{3}{*}{016} & \multirow[t]{3}{*}{ Metal products } & 041 & Iron and steel & 042 & Iron and steel \\
\hline & & 042 & Non-ferrous metal & 043 & Non-ferrous metal \\
\hline & & 043 & Metal products & 044 & Metal products \\
\hline \multirow[t]{11}{*}{017} & \multirow[t]{11}{*}{ Machinery } & 044 & Boilers, Engines and turbines & $045 \mathrm{E}$ & \begin{tabular}{|l|l|} 
Engines and turbines \\
\end{tabular} \\
\hline & & 045 & General machinery & $045 \mathrm{C}-2$ & Ordinary industrial machinery \\
\hline & & 046 & Metal working machinery & 045B-1 & Specialized industrial machinery \\
\hline & & & & $045 \mathrm{C}-2$ & Ordinary industrial machinery \\
\hline & & 047 & Specialaized machinery & 045A & Agricultural machinery \\
\hline & & & & $045 \mathrm{~B}-2$ & Specialized industrial machinery \\
\hline & & 048 & Heavy Electrical equipment & C45D & Heavy Electric machinery \\
\hline & & 049 & Television sets, radios,audios and communication equipment & \multirow[t]{4}{*}{ 1046A } & \multirow[t]{4}{*}{ Electronics and electronic products } \\
\hline & & 050 & Electronic computing equipment & & \\
\hline & & 051 & \begin{tabular}{|l|l} 
Semiconductors and integrated circuits \\
\end{tabular} & & \\
\hline & & 052 & Other electronics and electronic products & & \\
\hline
\end{tabular}




\section{CONVERSION TABLE, AIO 24 SECTORS (Cont.)}

\begin{tabular}{|c|c|c|c|c|c|c|c|}
\hline & & & & 053 & Household electrical equipment & 1046B & Other electric machinery and appliance \\
\hline & & & & 054 & Lighting fixtures, batteries, wiring and others & & \\
\hline & & 018 & Transport equipment & 055 & Motor vehicles & 047A & Motor vehicles \\
\hline & & & & 056 & Motor cycles & 1047B-1 & Motor cycles and bicycles (Motor cycles) \\
\hline & & & & 057 & Shipbuilding & $048 \mathrm{~B}$ & Shipbuilding \\
\hline & & & & 058 & Other transport equipment & 047B-2 & Motor cycles and bicycles (Bicycles) \\
\hline & & & & & & 048A & Aircrafts \\
\hline & & & & & & $048 \mathrm{C}$ & Other transport equipment \\
\hline & & 019 & Other manufacturing products & 059 & Precision machines & 049 & Precision machines \\
\hline & & & & 060 & Other manufacturing products & 050B & Other manufacturing products \\
\hline 004 & Electricity, gas & 020 & Electricity, gas, and water supply & 061 & \begin{tabular}{|l|} 
Electricity and gas \\
\end{tabular} & 051 & Electricity, gas and water supply \\
\hline & and water supply & & & 062 & Water supolv & & \\
\hline 005 & Construction & 021 & Construction & 063 & Building construction & $052 \mathrm{~A}$ & Building construction \\
\hline & & & & 064 & Other construction & 052B & Other construction \\
\hline 006 & Trade and transport & 022 & Trade and transport & 065 & Wholesale and retail trade & $053 \mathrm{~A}$ & Wholesale and retail trade \\
\hline & & & & 066 & Transportation & $053 \mathrm{~B}$ & Transportation \\
\hline 007 & Services & 023 & Services & 067 & Telephone and telecommunication & $054 \mathrm{~A}$ & Telephone and telecommunication \\
\hline & & & & 068 & Finance and insurance & $054 \mathrm{~B}$ & Finance and insurance \\
\hline & & & & 069 & Real estate & 054D-1 & Other services \\
\hline & & & & 070 & Education and research & $054 \mathrm{C}$ & Education and research \\
\hline & & & & 071 & Medical and health service & 054D-2 & Other services \\
\hline & & & & 072 & $\begin{array}{l}\text { Restraunts } \\
\end{array}$ & 054D-3 & Other services \\
\hline & & & & 073 & Hotel & 054D-4 & Other services \\
\hline & & & & 074 & Other services & 1054D-5 & Other services \\
\hline & & & & 076 & \begin{tabular}{|l|} 
Unclassified \\
\end{tabular} & 056 & \begin{tabular}{|l|l|l|l|l} 
Unclassified \\
\end{tabular} \\
\hline & & 024 & Public administration & 1075 & Public administration & 055 & Public administration \\
\hline & & & FINAL DEMAND SECTORS & & & & \\
\hline 001 & Private consumption & 001 & Private consumption & 001 & Private consumption & 001 & Private consumption \\
\hline 002 & Governemtn consumption & 002 & Governemtn consumption & 002 & Governemtn consumption & 002 & Governemtn consumption \\
\hline 003 & Gross fixed capital formation & 003 & Gross fixed capital formation & 003 & Gross fixed capital formation & 003 & Gross fixed capital formation \\
\hline 004 & Changes in stocks & 1004 & Changes in stocks & 1004 & Changes in stocks & 004 & Changes in stocks \\
\hline & & & VALUE ADDED SECTORS & & & & \\
\hline 001 & Wages and salary & 001 & Wages and salary & 001 & Wages and salary & $\infty$ & Wages and salary \\
\hline 002 & Operating surplus & 002 & Operating surplus & 002 & Operating surplus & 002 & Operating surplus \\
\hline 003 & Depreciation & 003 & $\begin{array}{l}\text { Depreciation } \\
\end{array}$ & 003 & \begin{tabular}{|l} 
Depreciation \\
\end{tabular} & 0003 & Depreciation \\
\hline 004 & Indirect taxes less subsidies & 1004 & Indirect taxes less subsidies & 1004 & Indirect taxes less subsidies & 1004 & Indirect taxes less subsidies \\
\hline
\end{tabular}

